\title{
Smart Contract-based Gamification Scheme for College in Higher Education
}

\author{
Leli Honesti ${ }^{1}$, Qurotul Aini ${ }^{2}$, M Ikhsan Setiawan ${ }^{3}$, Nuke Puji Lestari Santoso ${ }^{4}$, Wahyu \\ Yustika Prihastiwi ${ }^{5}$ \\ 1,2Universiti Teknologi Malaysia, ${ }^{3}$ Narotama University, 4,5 University of Raharja \\ 1,2 Sultan Ibrahim Chancellery Building, Jalan Iman, 81310 Skudai, Johor, Malaysia \\ $3 \mathrm{JI}$ Arif Rahman Hakim No 51 Kota Surabaya Prov. Jawa Timur \\ 4,5 Modern, Jl. Jenderal Sudirman No.40, RT.002/RW.006, Cikokol, Kec. Tangerang, Kota \\ Tangerang, Banten 15117 \\ e-mail: leli.honesti@yahoo.com¹, aini@raharia.info², ikhsan01@yahoo.com³ \\ nuke@raharia.info ${ }^{4}$, wahyuyustika@raharja.info $^{5}$
}

\section{To cite this document :}

Honesti, L., Aini, Q., Setiawan, M.I., Santoso, N.P.L., \& Prihastiwi, W.Y. (2022). Smart Contract-based Gamification Scheme for College in Higher Education. Aptisi Transactions on Management (ATM), 6(2), 102-111.

DOI :

https://doi.org/10.33050/atm.v6i2.1533

\begin{abstract}
The Financial Scheme that plays an important role in helping students is the Gamification Scholarship Scheme. The Gamification scholarship scheme helps human life in the world of education. Gamification is an approach that uses elements in games or video games with the aim of motivating students in the learning process and maximizing feelings of enjoyment and engagement in the learning process. To encourage higher education, the government has done various things. However, there are several things that make it difficult for students to use it, such as distributing scholarships to students belonging to underprivileged families. The Gamification scholarship scheme is one of the most financially instrumental schemes in helping students, but it has not been verified which results in a lack of transparency between students and their respective Education Offices, then there is still a lack of tracking of application forms in this study, we propose a Smart Contract which addresses the lack of Scheme Scholarships for Colleges and Universities outlined above. It has four entities: Board of Education, Students, College and Bank. This Blockchain based smart contract has been developed to provide a user-friendly and transparent and constant environment between students and the education board. Blockchain platform has developed many applications but none can overcome the government scholarship scheme.
\end{abstract}

Keywords: Blockchain; Gamification; Scheme of Scholarship; Smart Contract

\section{Introduction}

The Ministry of Education and the Ministry of Human Resources design and manage the learning policy-making process. It also addresses the various student fees. National Scholarships that have been awarded by the government as well as External Scholarships offered by other countries are 2 types of scholarships provided by the Department of Main Studies. In order to present Big Learning and become a financial instrument in helping students for low-income families, this Gamification scholarship scheme plays an important role. There are 4 entities in this scheme: Learning Boards, Students, Large Schools and Banks. Currently the process of the Gamification scholarship scheme is student authentication that is being tried by the College and Learning Council. Student authentication tasks are handled manually by the two entities, of course this takes a lot of time. 
Students who take part in the Gamification scholarship scheme will send the scholarship directly to their respective bank accounts [1]. The Gamification scholarship scheme will later use a special platform [2]. We have been working continuously to improve the existing system, but there are still some zones that need to be improved to maximize and improve the current system, we hereby recommend Blockchain-based smart contracts for the Gamification scholarship scheme. The smart contract for the Gamification scholarship scheme aims to reduce the need for manual labor so that it does not take a lot of time, automating the existing system [3].

This research has 4 parts. In section 2 describes a related comparison of the Blockchain Platform. Section 3 describes the gamification of Scheme scholarships for students via Blockchain and smart contracts. Part 4 conclusion.

\section{Research Method}

In this study using blockchain technology, Blockchain was first created by Satoshi Nakamoto, blockchain has a very large level of security where the information contained in the blockchain is difficult to manipulate, but transparent, where users can easily check the authenticity of information, or the money system. highly secure Peer to Peer electronics [4]. Blockchain has many applications in the financial and non-financial fields. Ethereum is a very well known Blockchain platform [5]. Within Ethereum there are platforms for scaling up smart contracts as well as distributed Applications. Various applications have shifted to the Blockchain platform using smart contracts [6]. Among other things, applications in agriculture, e-waste management, health and business applications but regarding smart contact based scholarships have not been proposed [7].

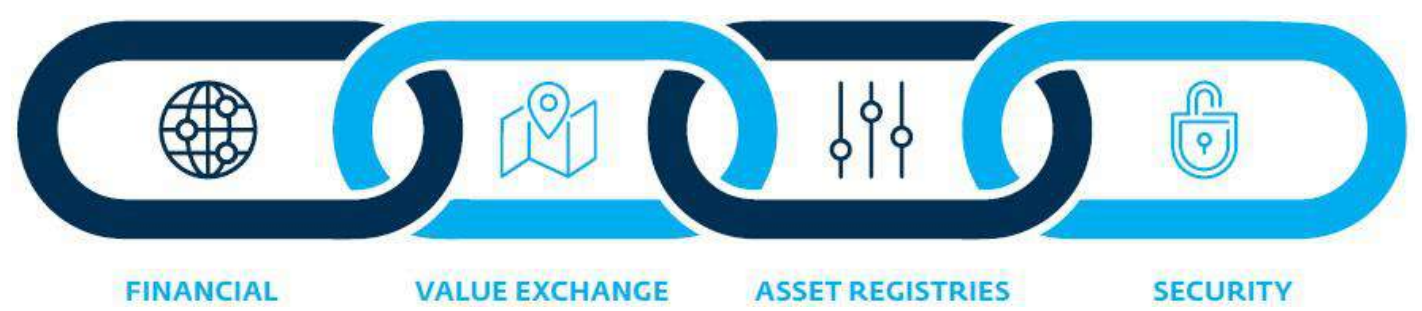

Fig. 1. Blockchain Value

The picture above is a Blockchain Value Chain, which starts from the left of Financial, for example the use of Blockchain is Banking [8]. On the right, there is a Value Exchange, or more easily imagined is the cash transformer for computerized money. For the record, if we have a payment card from a bank such as e-cash, streak and so on, it is not an advanced currency, the currency is Rupiah, it's just computerized recording. Then where is the advanced currency? For example Bitcoin, Etherium, and others [9]. On the right again is the Asset Register, examples of using Blockchain here are Supply Chain Management, gold and diamond transactions, and others. And the most right is Security, an example of using Blockchain here is Digital Identity Management. Customer identities can be found for Know Your Customer and Anti Money Laundering (KYC / AML) tracking [10].

\section{Results and Analysis}

Part 3 of this research explains Gamification scholarship scheme, basic concepts of Blockchain and smart contracts

\subsection{Gamification Scholarship Scheme}

This Gamification scholarship scheme is one of the scholarships offered by the Ministry of Education. The purpose of this scheme is to help students from low-income families. At Rahara 
University there are 1,000 students registered in this Gamification scholarship scheme which is given to both male and female students. Requirements for students who are eligible to register, the grade on the high school diploma must average six, domiciled in the city of Tangerang, have a letter of assistance from the urban village [11]. Students who have successfully registered will get a question in which there are 100 questions in total, if the student succeeds in answering step1 all correctly then the student will get points and these points can be collected or exchanged for offers available on the platform to get a score at least 85 of the questions on the gamification scholarship scheme platform [12].

How the Existing Gamification scholarship Scheme Works: Every June-July an application form is released [13]. The platform is used by students to apply for scholarships. Students fill out the form and requirements that have been directed [14]. After that, students will get a notification on each email if they meet the criteria. If they meet the criteria, students can immediately log back in to the gamification scholarship scheme platform and will get a fund of IDR 3,000,000 in 3x24 hours [15]. Verification and validation of the registration form is done manually. The status of an active or inactive bank account will not be checked by the authorities, the scholarship funds will be returned to the Learning Board if the scholarship recipient's bank account is inactive [16].

\subsection{Blockchain}

Technological developments have resulted in the emergence of a new technology called blockchain, this technology has advantages in terms of security, because it is a recorder that records open transactions and uses a decentralized database without going through third party intermediaries [17]. Initially blockchain was only used for transactions from encrypted electronic currencies such as bitcoin, but along with more in-depth research on developing currencies, blockchain technology is increasingly developing, not only for making transactions, but this technology is also related to existing technology [18]. like topology. network, cryptography, and consensus algorithms. Current technological advances are very influential for an organization [19].

Table 1. Field in the books

\begin{tabular}{|l|c|c|}
\hline \multicolumn{1}{|c|}{ Fields in the bloks } & Size of the fields in Bytes & Description of the field \\
\hline Block Size & 4 & 2 \\
\hline Block Header & 80 & 4 \\
\hline Transactions & $1-9$ & 6 \\
\hline
\end{tabular}

Interestingly, the block header contains various fields like previous hash, root merkle, timestamp, problem target and that's what makes the block different [20]. Table 2 will describe these areas. With blockchain, cryptographic hashes.

Table 2. Fields in the Block Header

\begin{tabular}{|l|c|l|}
\hline \multicolumn{1}{|c|}{ Field } & Size of the field in the bytes & \multicolumn{1}{|c|}{ Description of the field } \\
\hline previous Hash & 32 & Reference to previous block \\
\hline Market Root & 32 & The root of market tree \\
\hline Nonce & 4 & $\begin{array}{l}\text { Counter Used in block } \\
\text { mining }\end{array}$ \\
\hline
\end{tabular}

Each block contains transactions in which these transactions are similar to bookkeeping records that have multiple entries in them [21]. Each transaction has several entries that act to bill 
the user and one or more outputs, to which the user account is added credit [22]. It is not important that all the information and results be summarized in the same amount, but the results can be summarized into slightly less information [23]. This difference is referred to as an exchange fee, it is a small amount that is charged by miners to put transactions into blocks which are then loaded on the Blockchain [24].

If you want to make transactions, users need to download a computerized currency wallet (digital currency) which contains several public keys and private keys [25]. Transactions are framed by selecting important sources of information and outcomes, as shown by the sender and the sender specifying only the recipient and the amount to be transferred [26]. The complexity of the work in them is kept away from the sender. When an exchange is framed, it is tagged with the sender's private key using the Elliptic Curve Digital Signature Algorithm. Once this exchange is created by the closest center of the Blockchain organization, this central point then checks its trustworthiness by confirming follow-up alerts using the sender's public key. It is also checked that the information specified in the exchange is not used or not [27]. If the Exchange document is effectively checked, then it is stored in the Transaction pool [28]. Transaction pool is a store for various transactions not included in any block to date. The exchange is carried out at the Bitcoin organization, but has been removed from the Blockchain until recently [29]. Mining is a cycle of remembering square swaps after confirming them. Confirmation by calculation is the basis of the Bitcoin framework. The exchanges are chained into blocks, which require a lot of computation. In 32 bytes Digger collects exchanges from the exchange pool and creates a Merkle tree to encapsulate all exchanges [30]. The square header is also developed by the new box according to the configuration. At that time, using the Proof-of-Work calculation, the digger can approve the newly created box [31]. After mining, the digger broadcasts the newly created box on top of the Blockchain organization. The center point and the different diggers at that time confirmed the square. This box is then attached to the Blockchain if there is agreement about the accuracy of the Blockchain organization [32].

\subsection{Smart Contract}

Smart Contract is a term used to describe a self-functioning PC program protocol that runs naturally when certain conditions are met. American PC Nick Szabo in 1994 made a sharp contract. The sale and purchase of products, genuine inheritance, protection and so on are made possible by Smart Contracts [33]. Smart Contracts perform the necessary activities when the necessary conditions are met. There are Smart Contract preferences as follows [34]:

- Independence: Smart agreements remove the prerequisite for outsiders.

- Speed: Manual checks and handling records take a lot of time causing delays in cycle completion. Smart Contracts are a programmable cycle and require no human involvement which saves valuable time.

- Reliability: Data on the Blockchain cannot be deleted or changed.

- Fault: The absence of human impedance, human error is unlikely.

- Bank: smart contact provides a lot of reserve funds due to fee waivers for third parties.

Lack of guidelines: Not many laws for Blockchain, Smart Contracts, and cryptocurrencies in the legal field around the world to date.

- Tough execution: It takes a lot of effort to devise brilliant agreement terms for elements of today's reality.

- Changing the impossible smart contract: favorable situations are one of the significance of a brilliant deal can happen.

- to be detrimental. It cannot be applied for a meeting to change the current conditions in the Smart agreement. 
The gamification scholarship scheme relies on four individual substances. The substance is the Board of Education, Students, Universities, especially Banks. This substance is described in the attached subsection in detail [35]. The first step in this cycle is Smart Contract submission. As per the rules of the Gamification Scholarship Scheme, the top 1,000 students must be selected who can apply for grants [36]. The Board of Education is responsible for selecting attractive students depending on their level of footprint in class. Students who apply for grants will be confirmed by this staff with a file provided by the student [37]. Within the proposed framework, elements compared to Education Boards have been mechanized with the help of Smart Contracts [38]. From the school's information premise, the best 500 students will be selected to get a grant [39]. When a student applies for a scholarship, certain checks will be carried out by the system, because if the student gets a place with the best 500 students, otherwise the student doesn't exist eligible for the application structure and not eligible for a grant [40]. Banks and Colleges also need to confirm students. After confirmation by the bank and school elements, students will be added to the Blockchain for a very long time for graduation. The students must be effectively validated by the Smart Contract and then on a predetermined date the students will receive assistance in their respective ledgers. The manual work expected to perform report validation is no longer required, as verification is carried out with care. When the disbursement period after the course is over, Smart Contracts exclude students from Blockchain [41]. Keen's Contract for Gamification scholarship scheme uses a web interface for application form contributions and confirms student intricacies from the Board of Education's own information premise [42].

Fig. 2 displays the login entries for the student. In the current Gamification scholarship scheme setting, students can apply to benefit from the plan, and will be able to track their status. This registration is completed by filling in the online structure on the gamification scholarship scheme platform [43]. This structure captures the intricacies of students and banks. In the Smart Agreement on the gamification scholarship scheme, all students who are initially registered are required to enter using the transfer number, number, year of graduation, as well as their KTP and diploma. If the above is verified efficiently, then students are diverted to fill in the structure of the gamification scholarship scheme.

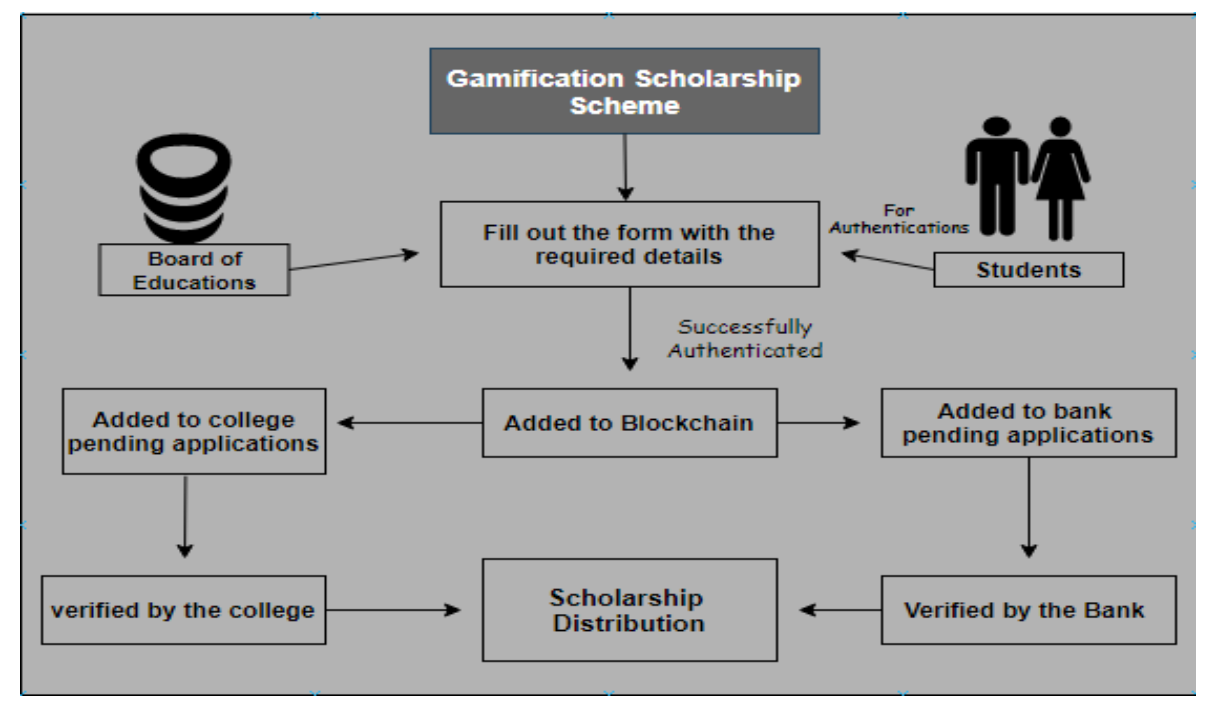

Fig. 2. Interaction between the Board of Education, Students, Colleges, and the Bank 


\section{Scholarship Application Form}
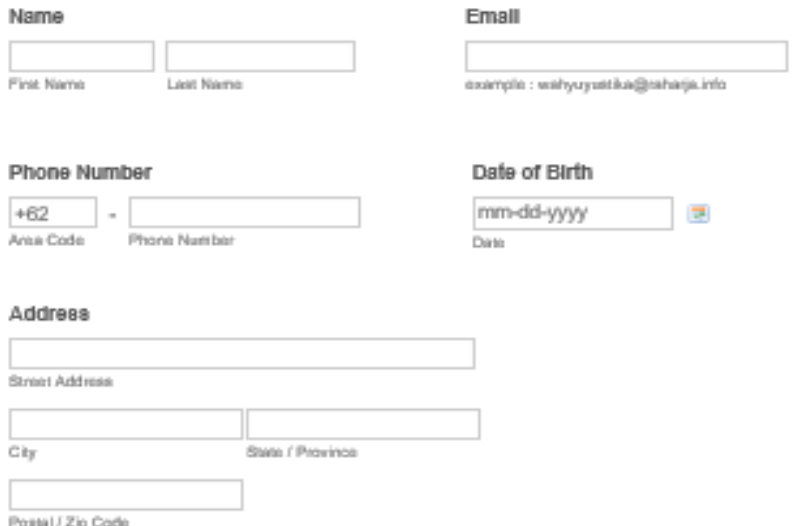

Upload Photos of Identtly Card, Famally Card and Diplomas (Front and Back). You CAn Upload Multiple Flles

Browse Fles

Upload Your Parent's Monthly Income

Browse Fles

Fig. 3 Entrance portal for students

- Main Academy: The task of the school substance in the Gamification scholarship Scheme is to check whether a particular student is enrolled in their school or not. This growth is seen in Photo 3. Approved school staff can refresh the intricacies of incoming applications after entry with their documents. This subtlety is the level of traceability and search participation after the course [44]. It also refreshes the level of the student's footprint and participation in the courses he is eyeing. Using this subtlety, the board of education can justify that certain students comply with the requirements for the program. Within the proposed framework, whenever a student fills in the structure of the Gamification scholarship Scheme efficiently, an application that will arrive immediately for the school is made [45].

\begin{tabular}{|c|c|c|c|c|c|}
\hline \multicolumn{6}{|c|}{ Student Score Update } \\
\hline No & $\begin{array}{l}\text { Registration } \\
\text { number }\end{array}$ & $\begin{array}{l}\text { Student } \\
\text { Name }\end{array}$ & $\begin{array}{l}\text { Answer the } \\
\text { question } \\
\text { correctly }\end{array}$ & Score & Gift \\
\hline 1 & 1 & Anggun Oktariyani & 98 & 980 & \\
\hline 2 & 3 & Irsa Rizkita & 68 & 680 & \\
\hline 3 & 2 & Mey Anggraeni & 89 & 890 & \\
\hline
\end{tabular}

Fig 4. Display of total student scores on the gamification scholarship scheme 
In the Gamification scholarship Scheme Smart Contract, whenever a student efficiently demonstrates the structure of his application, a student financial balance information column with extra fields to emphasize dynamic or non-dynamic status is created in Pending Bank Applications. This development is shown in Photo 4. This is an important step that must be taken because, if the status of the student's major novel is not dynamic, a notification can be made to confirm that the student changes the status of his financial balance which is not included in the framework [46].

\begin{tabular}{|c|c|c|c|}
\hline \multicolumn{4}{|c|}{ Update Bank Account Status } \\
\hline No & $\begin{array}{l}\text { Bank Account } \\
\text { Number }\end{array}$ & $\begin{array}{l}\text { Account Holder } \\
\text { Name }\end{array}$ & Active Status \\
\hline 1 & 5935674665 & Anggun Oktariyan & \\
\hline 2 & 5976254637 & Mey Anggraeni & \\
\hline 3 & 5987361286 & Irsa Rizkita & \\
\hline
\end{tabular}

Fig 5. Display of student account status bank in Smart Contract

Smart Contracts have been created to test the legal work of the proposed framework. And it is an open source feature used to investigate, compile, and test Solidity Smart Contracts. Elements characterized in segment 4 are executed in Solidity and Java Server Pages (JSP) using NetBeans. NetBeans is an air of coordinated enhancement. This threat was tried using Kali Linux 2019. 1a. The application efficiently copes with the incursions referred to in Table 1. The Smart Contract website interface attempts to fight against various incursions.

We implemented a time booster in our application by changing the frame clock but this was prevented efficiently by always synchronizing the clock work. Smart Contracts for Gamification Scholarship Schemes are tested by running various threats. The next threat is a phishing attack. Phishing threats are non-negotiable with our application due to the presence of Google Recaptcha in our application. The next threat we face is a coded animal threat collection bot that is actualized by java content and has been successfully prevented with the push of Google Recaptcha.

Ganache reproduces individual Ethereum Blockchains and is intrinsically validating against Sybil, Race, and Eclipse attacks. Our application also corrects against Sybil invasion, Race invasion and Eclipse invasion due to Ganache. Ganache performs Casper calculations to avoid Sybil. This threat is bypassed to prevent an approaching and active association in Ganache. Ganache automatically mines the exchange and upgrades it to the box when sent to the Ethereum organization so race attacks are not a module of the app. Replay assault can be tried in the application because it is based on a non-fork blockchain. However, threats can be prevented using HTTPS agreements and Denial of Service attacks can also be prevented using blockchain business sessions such as Hyperledger, R3 Corda, and Hashgraph.

\section{Conclusion}

In the current gamification scholarship scheme system, there are several challenges such as no detectable utilization structure, lack of openness between students and the Learning Board, and no major novel confirmation. In this paper, Smart Contracts have been planned and implemented for a Blockchain-based gamification Scholarship Scheme for College Students. With 
the current robotization gamification scholarship scheme, students who focus on different examinations are identified in a mechanical framework by the structure of the monitor application, students not only get funds, students will also get gifts if the student answers the questions correctly. With blockchain driven, we have the option to achieve candor between the student element as well as the Learning Board element.

Furthermore, the proposed Framework is ready to efficiently deal with the problems mentioned above. The gamification scholarship scheme consists of 4 substances including; Study Boards, Students, Large Schools, and Banks. Blockchain-based Smart Contracts for Gamification scholarship schemes provide easy-to-understand weather for students as well as protect the direct bond between students and their dedicated Learning Board. Smart agreement website interface is efficiently tried against Denial of Service attack, Time-Jacking attack, Phishing attack, Man in the center attack, Brute power attack on password using bots, Sybil attack, Eclipse attack, Replay attack, Overflow attack, Invasion Underflow, as well as the Race invasion but ran aground against the Denial-of-Service invasion and the Man in the Middle invasion.

In the next period, Smart Contract testing will be attempted on attacks such as Impersonation Proof attacks, Stage Hijacking attacks and Quantum calculation based attacks. to make it more comfortable and warm, Currently the situation is limited by the website application. It is possible to reach out to such a committed mobile phone application in the future.

\section{References}

[1] C. Eka, N. P. L. Santoso, S. Amelia, and V. T. Devana, "Pelatihan Software Editing Bagi Mahasiswa Pada Universitas Raharja," ADI Pengabdi. Kpd. Masy., vol. 1, no. 2, pp. 6065, 2021.

[2] S. Santoso, J. Kauf, and N. C. Aristo, "The Information System of Name Card Sales Based on Digital Marketing to Improve Creativepreneur on College E-Commerce Website," Aptisi Trans. Technopreneursh., vol. 1, no. 1, pp. 64-72, 2019.

[3] T. Alam, "Cloud Computing and its role in the Information Technology," IAIC Trans. Sustain. Digit. Innov., vol. 1, no. 2, pp. 108-115, 2020.

[4] Q. Aini, N. Lutfiani, N. P. L. Santoso, S. Sulistiawati, and E. Astriyani, "Blockchain For Education Purpose: Essential Topology," Aptisi Trans. Manag., vol. 5, no. 2, pp. 112-120, 2021.

[5] Henderi, Q. Aini, N. P. L. Santoso, A. Faturahman, and U. Rahardja, "A proposed gamification framework for smart attendance system using rule base," J. Adv. Res. Dyn. Control Syst., vol. 12, no. 2, pp. 1827-1838, 2020, doi: 10.5373/JARDCS/V12I2/S20201226.

[6] P. A. Sunarya, U. Rahardja, L. Sunarya, and M. Hardini, "The Role Of Blockchain As A Security Support For Student Profiles In Technology Education Systems," InfoTekJar J. Nas. Inform. dan Teknol. Jar., vol. 4, no. 2, pp. 13-17, 2020.

[7] A. Dudhat, N. P. L. Santoso, S. Santoso, and R. Setiawati, "Blockchain in Indonesia University: A Design Viewboard of Digital Technology Education," Aptisi Trans. Technopreneursh., vol. 3, no. 1, pp. 68-80, 2021.

[8] B. S. Riza, "Blockchain Dalam Pendidikan: Lapisan Logis di Bawahnya," ADI Bisnis Digit. Interdisiplin J., vol. 1, no. 1, pp. 41-47, 2020.

[9] L. Chandra, Amroni, B. Frizca, Q. Aini, and U. Rahardja, "Utilization Of Blockchain Decentralized System In Repairing Management Of Certificate Issuance System," J. Adv. Res. Dyn. Control Syst., vol. 12, no. 2, pp. 1922-1927, 2020, doi: 10.5373/JARDCS/V12I2/S20201235.

[10] C. Lukita, M. Hatta, E. P. Harahap, and U. Rahardja, "Crowd funding management platform based on block chain technology using smart contracts," J. Adv. Res. Dyn. Control Syst., vol. 12, no. 2, 2020, doi: 10.5373/JARDCS/V12I2/S20201236.

[11] N. Lutfiani, E. P. Harahap, Q. Aini, A. D. A. R. Ahmad, and U. Rahardja, "Inovasi Manajemen Proyek I-Learning Menggunakan Metode Agile Scrumban," InfoTekJar J. Nas. Inform. dan Teknol. Jar., vol. 5, no. 1, pp. 96-101, 2020. 
[12] Q. Aini, U. Rahardja, N. P. L. Santoso, and A. Oktariyani, "Aplikasi Berbasis Blockchain dalam Dunia Pendidikan dengan Metode Systematics Review," CESS (Journal Comput. Eng. Syst. Sci., vol. 6, no. 1, pp. 58-66, 2021.

[13] S. Khanna, "ICT Enabled Learning: A tool in Crisis Management," Aptisi Trans. Technopreneursh., vol. 2, no. 2, pp. 127-130, 2020.

[14] Q. Aini, U. Rahardja, M. R. Tangkaw, N. P. L. Santoso, and A. Khoirunisa, "Embedding a Blockchain Technology Pattern Into the QR Code for an Authentication Certificate," $J$. Online Inform., vol. 5, no. 2, 2020.

[15] I. Amsyar, E. Christopher, A. Dithi, A. N. Khan, and S. Maulana, "The Challenge of Cryptocurrency in the Era of the Digital Revolution: A Review of Systematic Literature," Aptisi Trans. Technopreneursh., vol. 2, no. 2, pp. 153-159, 2020.

[16] R. Aulia, A. Sururi, and S. Sukendar, "Effectiveness Of Featured Product Of Rural Areas Program (Prukades) In Improving The Economy Of Teluk Village Community Pandeglang Regency," ADI J. Recent Innov., vol. 2, no. 1 Sept, pp. 204-211, 2020.

[17] A. S. Bist, W. Febriani, C. Lukita, S. Kosasi, and U. Rahardja, "Design of Face Recognition AttendX for Recording Student Attendance Data Based on Artificial Intelligence Technology," Solid State Technol., pp. 4505-4518, 2020.

[18] S. Sutirna, "TOTAL QUALITY MANAGEMENT THROUGH LECTURER ASSESSMENT WITH STUDENTS TO IMPROVE GRADUATE QUALITY," ADI $J$. Recent Innov., vol. 2, no. 1 Sept, pp. 227-242, 2020.

[19] N. Lutfiani, F. P. Oganda, C. Lukita, Q. Aini, and U. Rahardja, "Desain dan Metodologi Teknologi Blockchain Untuk Monitoring Manajemen Rantai Pasokan Makanan yang Terdesentralisasi," InfoTekJar J. Nas. Inform. dan Teknol. Jar., vol. 5, no. 1, pp. 18-25, 2020.

[20] A. Williams and E. Dolan, "Application of Blockchain Technology in e-LoA Technopreneurship Journal," Aptisi Trans. Technopreneursh., vol. 2, no. 1, pp. 98-103, 2020.

[21] U. Rahardja, A. Singh Bist, M. Hardini, Q. Aini, and E. P. Harahap, "Authentication of Covid-19 Patient Certification with Blockchain Protocol," Int. J. Adv. Sci. Technol., vol. 29, no. 8s, pp. 4015-4024, 2020.

[22] Q. Aini, A. Badrianto, F. Budiarty, A. Khoirunisa, and U. Rahardja, "Alleviate Fake Diploma Problem In Education Using Block Chain Technology," J. Adv. Res. Dyn. Control Syst., vol. 12, no. 2, pp. 1821-1826, 2020, doi: 10.5373/JARDCS/V12I2/S20201225.

[23] Z. Fauziah, H. Latifah, X. Omar, A. Khoirunisa, and S. Millah, "Application of Blockchain Technology in Smart Contracts: A Systematic Literature Review," Aptisi Trans. Technopreneursh., vol. 2, no. 2, pp. 160-166, 2020.

[24] Q. Aini, P. A. Sunarya, and A. S. Bein, "The Implementation Of Viewboard Of The Head Of Department As A Media For Student Information Is Worth Doing Final Research," IAIC Trans. Sustain. Digit. Innov., vol. 1, no. 1, pp. 18-25.

[25] K. Arora, A. S. Bist, R. Prakash, and S. Chaurasia, "A Novel Approach for Facial Attendance: AttendXNet," Aptisi Trans. Technopreneursh., vol. 2, no. 2, pp. 104-111, 2020.

[26] R. Rojali and D. I. Sari, "Relationship Of Individual Characteristics, Physical Home Environment And Behavior With The Incidence Of Pulmonary Tb In Cijoro Pasir Village, Muara Village East Ciujung And West Rangkasbitung Village, Rangkasbitung Subdistrict, Lebak Regency 2019,” ADI J. Recent Innov., vol. 1, no. 2, pp. 167-179, 2020.

[27] Q. Aini, A. Alwiyah, and D. M. Putri, "Effectiveness of Installment Payment Management Using Recurring Scheduling to Cashier Performance," Aptisi Trans. Manag., vol. 3, no. 1, pp. 13-21, 2019.

[28] A. Muhtadibillah, H. T. Sukmana, and N. F. Rozy, "An Evaluation Of Helpdesk With Gamification Using Indeks Kepuasan Masyarakat (IKM)," IAIC Trans. Sustain. Digit. Innov., vol. 1, no. 1, pp. 8-17, 2019. 
[29] M. Kamil, A. S. Bist, U. Rahardja, N. P. L. Santoso, and M. Iqbal, "Covid-19: Implementation e-voting Blockchain Concept," Int. J. Artif. Intell. Res., vol. 5, no. 1, 2021.

[30] U. Rahardja, T. Hariguna, Q. Aini, and S. Santoso, "Understanding of behavioral intention use of mobile apps in transportation: An empirical study," Int. J. Adv. Trends Comput. Sci. Eng., vol. 8, no. 1.5 Special Issue, pp. 258-263, 2019, doi: 10.30534/ijatcse/2019/4581.52019.

[31] A. Asmawati, F. J. E. Putra, and L. Richie, "Control Led Through Internet Based On Nodemcu With Blynk Application," Aptisi Trans. Technopreneursh., vol. 1, no. 2, pp. 170-179, 2019.

[32] R. Kurniawan, A. Sutawan, and R. Amalia, "Information System Ordering Online Restaurant Menu At Hover Cafe," Aptisi Trans. Manag., vol. 4, no. 1, pp. 32-40, 2020.

[33] A. Adiyanto and R. Febrianto, "Authentication Of Transaction Process In E-marketplace Based On Blockchain technology," Aptisi Trans. Technopreneursh., vol. 2, no. 1, pp. 6874, 2020.

[34] A. S. Bein, Y. I. Graha, and A. P. Pangestu, "Pandawan Website Design Based Content Management System As Media E-commerce Transaction," Aptisi Trans. Technopreneursh., vol. 2, no. 1, pp. 87-97, 2020.

[35] A. Argani and W. Taraka, "Pemanfaatan Teknologi Blockchain Untuk Mengoptimalkan Keamanan Sertifikat Pada Perguruan Tinggi," ADI Bisnis Digit. Interdisiplin J., vol. 1, no. 1, pp. 10-21, 2020, doi: 10.34306/abdi.v1i1.121.

[36] G. G. Wiguna, K. Darkun, and K. Sulistyadi, "SAST \& AHP METHOD IN DETERMINING THE BEST STRATEGY OF OFFICE ERGONOMICS PROGRAM IMPROVEMENT TO PREVENT RISK OF MUSCULOSKELETAL DISORDERS AT XYZ COMPANY QATAR,” ADI J. Recent Innov., vol. 2, no. 1, pp. 7-14, 2020.

[37] A. Suryadi, P. T. Asmoro, and A. Solihin, "Hybrid Electric Power Plant Using Wind Turbine Savonius Helix and Solar Cell as an Alternative Power Source in the Lightning Tower at Flashing Lights," ADI J. Recent Innov., vol. 1, no. 1 Sept, pp. 1-6, 2019.

[38] S. Sudaryono, U. Rahardja, and D. Apriani, "The CICES Journal Governance Performance Improvement on Quality of Current Issues (Case Study of STMIK RAHARJA)," Aptisi Trans. Manag., vol. 3, no. 1, pp. 57-64, 2019.

[39] A. I. L. Wibowo, A. D. Putra, M. S. Dewi, and D. O. Radianto, "Differences In Intrinsic Value With Stock Market Prices Using The Price Earning Ratio (Per) Approach As An Investment Decision Making Indicator (Case Study Of Manufacturing Companies In Indonesia Period 2016-2017)," Aptisi Trans. Technopreneursh., vol. 1, no. 1, pp. 82-92, 2019.

[40] N. K. Purnamawati, A. M. Adiandari, N. D. A. Amrita, and L. P. V. I. Perdanawati, "The Effect Of Entrepreneurship Education And Family Environment On Interests Entrepreneurship In Student Of The Faculty Of Economics, University Of Ngurah Rai In Denpasar," ADI J. Recent Innov., vol. 1, no. 2 Maret, pp. 158-166, 2020.

[41] F. Sudarto and A. Yondari, "Web-Based Population Cencus Design In Neighborhood Building," Aptisi Trans. Technopreneursh., vol. 2, no. 1, pp. 18-24, 2020.

[42] T. Alam and M. Aljohani, "Software Defined Networks: Review and Architecture," 2020.

[43] E. Guustaaf, U. Rahardja, Q. Aini, H. W. Maharani, and N. A. Santoso, "Blockchain-based Education Project," Aptisi Trans. Manag., vol. 5, no. 1 January, pp. 46-61, 2021.

[44] S. Watini, Q. Aini, M. Hardini, and U. Rahardja, "Drawing Competency Development Using the Atik Model in Kindergarten (TK)," Solid State Technol., pp. 4519-4528, 2020.

[45] N. F. Rozy, R. Ramadhiansya, P. A. Sunarya, and U. Rahardja, "Performance Comparison Routing Protocol AODV, DSDV, and AOMDV with Video Streaming in Manet," 2019 7th Int. Conf. Cyber IT Serv. Manag. CITSM 2019, 2019, doi: 10.1109/CITSM47753.2019.8965386.

[46] S. Sayyida and A. Alwiyah, "Phenomenon Of SMEs (Small and Medium Enterprises) and Community Mindset," Aptisi Trans. Manag., vol. 4, no. 2, pp. 101-106, 2020. 